Tropical Journal of Pharmaceutical Research, December 2003; 2 (2): 229-234

(C) Pharmacotherapy Group,

Faculty of Pharmacy, University of Benin,

Benin City, Nigeria.

All rights reserved.

Available online at http://www.tjpr.freehosting.net

Research Article

\title{
Microbial contamination and preservative capacity of some brands of cosmetic creams
}

\author{
Peter G Hugbo, Anthony O Onyekweli and ljoma Igwe ${ }^{\Phi}$ \\ Faculty of Pharmacy, University of Benin, Benin City, Nigeria
}

\begin{abstract}
Purpose: Cosmetic and topical products need not be sterile but may contain low levels of microbial load during use. This study was conducted to determine and compare the level and type of microbial contaminants in commercial cosmetic products sold in the market and a laboratory prepared aqueous cream and their preservative capacities while in use.

Methods: Ten brands of commercially available cosmetic creams and lotions were randomly purchased from the open markets in Benin City. Aqueous Cream was also prepared. Their bacterial and fungal loads as well as types were evaluated. Preservative capacity was evaluated by challenging the creams and lotions with washed and characterized isolates of Staph. aureus and viable counting was performed by the surface viable method. The prepared aqueous cream was similarly challenged with the test organism.

Results: All the products were contaminated to varying degrees. Staphylococci and other gram-positive cocci were the most preponderant; gram-negative isolates were hardly found. Fungal contaminants consisted largely of Asp. fumigatus, Penicillium and Microsporium species. Challenge test (re-infection) with Staph. aureus revealed the commercial products as having low capacity for suppressing bacterial proliferation such as may be encountered during in - use contamination.

Conclusion: Commercial cosmetic creams and lotions evaluated did not generally meet the standards for microbial limits as specified in official monographs. Such products can adversely affect health status of consumers as well as the stability profiles of the products.
\end{abstract}

Key words: Commercial products; cosmetic creams; cosmetic lotions; microbial contamination.

$\boldsymbol{\Phi}_{\text {To whom correspondence should be addressed }}$ 


\section{Hugbo et al., 2003}

\section{Introduction}

The warm and rather humid climatic conditions that prevail in most tropical countries, including Nigeria, would tend to support the survival and growth of many microorganisms. In a situation whereby a nutritionally rich pharmaceutical/cosmetic product is severely contaminated, rapid growth and multiplication would be expected. This could lead to biodegradation of the product and hence the risk of infection to consumers of the product ${ }^{1}$. Product contamination may arise from raw materials or water used in formulation or accidentally, during use. Studies carried out till date ${ }^{2-6}$ to assess the incidence and hygienic status of many topical products, do not sufficiently simulate actual - use conditions of the products in the sense that laboratoryprepared sterile creams are frequently used in the challenge tests ${ }^{7}$. Such studies do not, therefore, realistically monitor the true capacity of the cream to suppress accidental in-use contamination; a very important consideration for successful preservation.

This paper reports the results of evaluation of ten cosmetics skin preparations and a laboratory prepared non-sterile cream for the load and type of microbial contamination and also, the ability of such products to consistently suppress the multiplication of microbial contaminants with which they were challenged.

\section{Experimental}

Ten (10) skin preparations consisting of 6 creams and 4 lotions were purchased from the open markets in Benin City. Two of the products were made by a major home-care product manufacturer in Lagos, 1 was imported, 5 were made by smaller local manufacturing companies while the manufacturer(s) of the remaining 2 products was not indicated. The container labels and contents were carefully examined and noted. Date of manufacture and of expiry, preservative used, if any, as well as the composition were noted. Aqueous cream $\mathrm{BP}^{8}$ was prepared using chlorocresol as the indicated preservative. All samples were maintained at $4{ }^{\circ} \mathrm{C}$ to minimize growth prior to use. Oxoid media (nutrient and Sabouraud) were used in all evaluations.

\section{Evaluation of microbiological quality of cosmetics}

Microbial contamination of cream/lotion was determined by thinly spreading a loopful of material withdrawn from the depths of the bulk product on nutrient and Sabouraud agars and incubating for $24-48 \mathrm{~h}$ at $37{ }^{\circ} \mathrm{C}$ and 5 days at $28-30{ }^{\circ} \mathrm{C}$ for bacteria and moulds, respectively. Isolates were purified and identified to species level using standard procedures.

In order to assess the degree of contamination, $1 \mathrm{~g}$ of material was dispersed in $4 \mathrm{ml}$ sterile Ringer solution containing $0.25 \%$ tween 80 . Appropriate dilutions were made in the same dispersing vehicle and 0.5 $\mathrm{ml}$ was plated out on the appropriate solid medium using the surface viable method. Emergent colonies were counted after the necessary incubation. All operations were carried out in duplicates.

\section{Challenge test for preservative capacity}

We hereby define "Preservative Capacity (PC)" of a product as the ability or power of that product to consistently maintain low and acceptable levels of microbial contaminants when such product is challenged with fresh microbial load(s), for which in cosmetic creams, the official specified limits are, not more than $1.0 \times 10^{3}$ for bacteria, and $1.0 \times 10^{2}$ for moulds $/ \mathrm{g} / \mathrm{ml}$ of the product ${ }^{8}$. In order to assess this capability of the products, $20 \mathrm{~g}$ of product was aseptically weighed into $50 \mathrm{ml}$ sterile conical flasks and stoppered with tight cotton wool plugs. The bacterial isolate that was most frequently identified as contaminant of the products, was employed as challenge inocula (Staph. aureus, Aspergillus fumigatus and Pencillium spp.). 
Mould contaminants were not evaluated along with the bacteria contaminants as these were not frequently isolated.

The Staph. aureus isolate was grown on over-night agar culture, harvested, and washed as described by Newton and Vickers $^{9}$, and re-suspended in $10 \mathrm{ml}$ diluent. Thereafter, $1 \mathrm{ml}$ of the suspension was used to inoculate each sample preparation and stored at ambient room temperature for 30 days $^{10}$. Periodically (on day 1, 2, 6, 12 and 30), $1 \mathrm{ml}$ sample of material was withdrawn for enumeration of bacterial survivors.

In all experiments involving both the commercial and laboratory prepared creams, uninoculated samples of each preparation served as baseline controls and growth and death values were expressed as logarithm of. percentage changes of these baseline counts.

\section{Results and Discussion}

Table 1 presents the container label disclosures for the 10 brands of cosmetic products evaluated. No product disclosed the date of manufacture and only 3 indicated the dates of expiry of their products. Nine of the 10 manufacturers gave indications of inclusion of a preservative/s but not the type of preservative used and only 4 manufacturers disclosed this information. One company did not even state whether a preservative was included at all. With regards to batch numbers, only 4 companies gave the batch numbers of the products, the other 4 companies did not.

These inadequacies and inconsistencies in container label disclosures should be viewed with serious concern. This is particularly so from the standpoint of non-disclosure of batch numbers; meaning that in the event of a defective product being inadvertently released into the market, recalls would be extremely difficult to effect.
Table 1: Container label disclosures on some cosmetic creams and lotions

\begin{tabular}{|c|c|c|c|c|c|}
\hline \multirow{3}{*}{ Product } & \multicolumn{5}{|c|}{ Product label disclosure } \\
\hline & \multirow{2}{*}{$\begin{array}{c}\text { Date of } \\
\text { Production }\end{array}$} & \multirow{2}{*}{$\begin{array}{l}\text { Expiry } \\
\text { date }\end{array}$} & \multicolumn{2}{|c|}{ Preservative } & \multirow{2}{*}{$\begin{array}{c}\text { Batch } \\
\text { No. }\end{array}$} \\
\hline & & & Any & Type & \\
\hline P01 & - & - & + & - & - \\
\hline PO2 & - & - & + & - & + \\
\hline PO3 & - & - & + & + & - \\
\hline PO4 & - & - & + & + & - \\
\hline PO5 & - & + & + & + & + \\
\hline PO6 & - & - & + & + & - \\
\hline PO7 & - & + & + & + & + \\
\hline P08 & - & + & + & - & + \\
\hline PO9 & - & - & - & - & - \\
\hline PO10 & - & - & + & + & - \\
\hline
\end{tabular}

+ implies Label disclosure provided; - implies label disclosure not provided

The dates of manufacture and of expiry are also vitally important and should be specified to provide guides as to the time frame for which the wholesomeness of a product can be reasonably assured.

\section{Physical appearance of products}

All the products, including the controls, that is, the aqueous cream and uninoculated branded cream maintained their original physical characteristics, for example, there was no change in their appearances such as colour, nor was there cracking or separation of phases of the creams.

\section{Microbiological quality of topical cosmetic products}

Qualitative tests showed that the creams were generally contaminated to varying degrees; 7 out of the 10 products had bacterial growths within $24 \mathrm{~h}$. of incubation and 9 in $48 \mathrm{~h}$, that is, 9 of the creams had bacterial contaminants and 7 had fungal contaminants. Most of the growths were however, scanty particularly with respect to the mould contaminants. Table 2 gives the quantitative bacterial and fungal counts 
Table 2: Microbial counts (CFU ml) and types found in creams and lotions

\begin{tabular}{|c|c|c|c|c|}
\hline \multirow{2}{*}{$\begin{array}{l}\text { Prepa- } \\
\text { ration }\end{array}$} & \multicolumn{2}{|c|}{ Bacteria } & \multicolumn{2}{|r|}{ Fungi } \\
\hline & Counts & Types & Counts & Types \\
\hline $\begin{array}{l}\mathrm{PO} 1 \\
\mathrm{PO} 2 \\
\mathrm{PO} 3 \\
\mathrm{PO} 4 \\
\mathrm{PO} 5 \\
\mathrm{PO} 6 \\
\mathrm{PO} 7\end{array}$ & $\begin{array}{l}2.25 \times 10^{3} \\
1.0 \times 10^{3} \\
1.0 \times 10^{3} \\
1.25 \times 10^{4} \\
2.25 \times 10^{3} \\
5.0 \times 10^{2} \\
1.0 \times 10^{3}\end{array}$ & $\begin{array}{l}\text { Staph. aureus } \\
\text { Staph., coag-ve } \\
\text { Staph, coag-ve } \\
\text { Bacillus spp. } \\
\text { Staph. aureus } \\
\text { Staph. Aureus } \\
\text { Staph. aureus } \\
\text { Staph. aureus } \\
\text { Staph. coag-ve }\end{array}$ & $\begin{array}{l}3.5 \times 10^{4} \\
- \\
3.0 \times 10^{3} \\
\text { Negative } \\
\text { Negative } \\
\text { Negative } \\
2.5 \times 10^{3}\end{array}$ & $\begin{array}{l}\text { Microsporium canis } \\
\text { Mucor spp. } \\
\text { Asp. fumigatus } \\
\text { Negative } \\
\text { Negative } \\
\text { Negative } \\
\text { Trichophyton spp. }\end{array}$ \\
\hline $\begin{array}{l}\text { PO8 } \\
\text { PO9 } \\
\text { PO10 } \\
\text { Aqueous } \\
\text { Cream (BP) }\end{array}$ & $\begin{array}{l}3.75 \times 10^{3} \\
6.5 \times 10^{3} \\
\text { Negative } \\
2.5 \times 10^{2}\end{array}$ & $\begin{array}{l}\text { Staph., coag-ve } \\
\text { Staph. aureus }\end{array}$ & $\begin{array}{l}2.0 \times 10^{3} \\
\text { Negative } \\
5.0 \times 10^{2}\end{array}$ & $\begin{array}{c}\text { Asp. Fumigatus. } \\
- \\
\text { Penicillin spp. }\end{array}$ \\
\hline
\end{tabular}

$(\mathrm{g} / \mathrm{ml})$ for each product evaluated. One product did not show bacterial growth; while 4 had no fungal counts, whatsoever. Counts in general ranged between $5.0 \times 10^{2}$ $1.25 \times 10^{4} \mathrm{cfu} \mathrm{m}^{-1}$ for bacteria and less for moulds. Most common bacterial contaminants were staphylococci spp. (9 out of 10) and Bacillus spp., while moulds were Asp. fumigatus, Microsporium canis and Penicillium spp. With regards to the aqueous cream, the initial count was very low $\left(1.5 \times 10^{2}\right)$; and the major isere was $B$. subtilis No moulds were isolated from this preparation.

On Mc Conkey agar, no bacteria were recovered, indicating the absence of Enterobacteriace and hence, probable adherence to good manufacturing protocol. Although the Enterobacteriaceae group was generally absent from the creams, the frequent isolation of Staph. aureus, Microsporium canis and Asp. fumigatus is of some concern because of the pathogenic potential of these organisms.

A cream with good preservative capacity is one that is capable of inhibiting immediate post-production contaminants as well as subsequent low inocula of in-use contaminants, and thereby maintains acceptable low levels of microorganisms in the preparation.

As earlier stated, challenge tests that are derived from laboratory prepared-sterile creams cannot closely simulate real situations that are normally encountered by the preparation. In our tests therefore, unsterile creams were challenged with washed bacterial suspensions and growth or otherwise, was monitored and then expressed by the difference between the challenged sample (test) and the unchallenged sample (control) under the same experimental conditions. The aqueous cream was in the same way subjected to the treatment.

Figure 1 shows the log percentage changes in bacterial populations in creams stored for 30 days at ambient temperature. For $\mathrm{PO}_{1}$ and $\mathrm{PO}_{2}$ there was initially a decrease in the bacterial populations for the first 12 days, but this was followed by a rapid increase of over 200 log percent in numbers. 
Samples $\mathrm{PO}_{3}, \mathrm{PO}_{4}, \mathrm{PO}_{5}, \mathrm{PO}_{6}, \mathrm{PO}_{7}$, and $\mathrm{PO}_{8}$ also displayed similar increases in the bacterial numbers, but these were at much reduced rates, attaining only 50-60 percent log increases. These indicate that the preservatives are not sufficiently potent and persistent in their antibacterial activities as to be able to maintain the preparation at the original level of post-production bacterial numbers or even less. Considering the aqueous cream, the picture was not markedly different, as there was an initial decline in bacterial counts for the first 2-6 days, only to be followed by a resurgence of growth though, at a much-reduced rate.

Label disclosures indicated that most of these creams were preserved with methylpropyl paraben combinations except product $\mathrm{PO}_{4}$ where the specific agent was not stated. Parabens are good cosmetic preservatives, as they possess most of the attributes desired of an ideal preservative compound. Unfortunately however, they lack broad spectrum of activity since they are more active against fungi and less so against bacteria $^{(11)}$. They also possess fairly high dilution coefficients ${ }^{(11)}$ and hence are not likely to exhibit persistent activity in presence of extraneous matter or upon dilution. An additional challenge inoculum would expectedly give rise to a large fall in residual concentration if the preservatives, which the manufacturers claimed to have used were, indeed parabens. These limitations probably in part, explain the higher bacterial loads and low capacity effect observed in these evaluations. Unlike the report of Okeke and Lamikanra ${ }^{(6)}$, Gram-negative bacilli were not seen in these studies, but like in their report, Salmonella spp. was also not isolated. Such outcomes would tend to imply the execution of reasonably good manufacturing protocol, but then the initial bacterial loads per gm. of material in 6 of the 10 samples exceeded $1 \times 10^{3}$ which is the acceptable bottom line for bacteria in non - sterile topical products ${ }^{(8)}$

\section{Conclusion}

The results presented in this study show that the preservatives employed in these cosmetic products did not possibly possess adequate preservative capacity to be able to bring about acceptable low levels of microbial contamination as demanded by regulatory bodies ${ }^{8}$. There is therefore, a pressing need to search for compounds with such additional properties if the microbiological wholesomeness of such products is to be ensured. The results further disclose that some cosmetic product manufacturers do not adopt a system of container label disclosure of their products; an aspect of production to which special attention must now be given if consumer confidence is to be assured.

\section{References}

1. Bos, CE, Van Doorne, $\mathrm{H}$ and OLerk, CF. Microbiological stability of tablets stored under tropical conditions. Inter. J Pharm. 1989; 55: 175-83.

2. Malcolm SA. The Survival of Bacteria in Toiletries. In: Skinner F and Hugo WB (ed.). Inhibition and Inactivation of Vegetative Microbes. London Acad Press, 1976, pp 305-14.

3. Baird RM and Shooter RA. Pseudomonas aeruginosa infections associated with the use of contaminated medicaments. Br Med J. 1976; 2: 349-50.

4. Myers GE and Pasutto FM. Microbiological contamination of cosmetics and toiletries. Can .J Pharm Sci. 1973; 8: 19-23.

5. Kallings LO, Ringertz $O$, Silverton $P E$ and Ernenfeldt F. Microbiological contamination of medical preparations. Acta Pharm Sci. 1966; 3: 219-228.

6. Becks $\mathrm{V}$ and Lorenzoni N. Pseudomonas aeruginosa outbreak in a neonatal intensive care unit: A possible link to contaminated hand Iotion. Amer J Inf Control. 1995; 23: 396-8.

7. Okeke IN and Lamikanra A. Bacteriological quality of skin moisturizing creams and lotions distributed in a tropical developing country. $J$ Appl Microbiol. 2001; 91: 922-8.

8. British Pharmacopoeia Appendix XV1B, Tests for microbial contamination. The Pharmaceutical Press, London, 1993. 


\section{Hugbo et al., $2003 \quad$ Contamination and preservation of creams}

9. Newton JM and Vickers JA. Response of standardized suspensions of Escherichia coli to iodine. J Pharm Pharmacol. 1964; 16: 381-5.

10. Manowitz M. Cosmetic Preservatives. In: Lawrence $\mathrm{CA}$ and Block SS (eds.). Disinfection, Sterilization and Preservation. Lea and Febiger; Philadelphia, 1968.
11. Lynn B and Hugo WB. Chemical disinfectants antiseptics and preservatives. In: Hugo WB and Russell AD. Pharmaceutical Microbiology. $3^{\text {rd }}$ Ed.. Blackwell Scientific Publications, UK, 1981. 